\title{
"I Guess They Didn't Want Us Asking \\ Too Many Questions": Reading American \\ Empire in Guam
}

Valerie Solar Woodward

U nited States narratives about its island possession Guam have emphasized notions of liberation and loyalty and uphold a picture of a benevolent and just America that provides freedom and opportunity to all who live under its flag. These narratives help to justify the current power regime and provide "authoritative narratives of the nation, delimit proper behavior of citizens, and sketch the parameters of the national imagination"; however, it is important to note that "narratives of nationhood ... are always unfinished projects" (Hein and Selden 2000, 3), and there are multiple channels through which a variety of narratives can be expressed. In this article, I examine texts by two authors that expand and sometimes challenge these narratives of Guam.

The texts-Mariquita: A Tragedy of Guam by Chris Perez Howard (I986) and three poems from Craig Santos Perez's book from unincorporated territory: [hacha] (2008)-demonstrate how these two authors utilize and manipulate the rhetorics of liberation and patriotism in order to claim a space for their own distinct voices while dealing with the complex history of Guam, citizenship, and American empire. These two examples are intriguing because of the ways that they illuminate how US imperialism has cloaked itself through the rhetoric of constitutional law, patriotism, and liberation from Japanese militarism.

Mariquita is a short biography regarding the tragic circumstances that the author's mother experienced during the World War II occupation of Guam by the Imperial Japanese Army. This text imagines Howard's mother, the Mariquita of the title, from her late teens through her courtship by the author's father, a naval enlisted man. It ends with her last days of forced servitude to Imperial Japanese forces followed by her execution. On first glance, this narrative follows the expected contours of pro-

The Contemporary Pacific, Volume 25, Number I, 67-9I

(C) 2013 by University of Hawai'i Press 
American and anti-Japanese sentiment and repeatedly stresses the marital and martial fidelity of the Perez-Howard family, but subsequent readings uncover a more nuanced and ambivalent picture.

Craig Santos Perez is a native Chamorro who has done graduate work in the United States at both the University of San Francisco and the University of California at Berkeley. In the chapbook from unincorporated territory [hacha], his academic and artistic concerns come together to illuminate the ways in which the dry language of law and politics can be infiltrated and inflated by the blood and tears of the peoples who are directly affected by those same laws. He begins with a preface that offers explanations of the title, of the marginalized status of Guam, and of how things as seemingly remote as US Supreme Court cases tried over a hundred years ago still affect his daily life. Perez claims that his poems are an "attempt to begin re-territorializing the Chamorro language in relation to my own body, by way of the page" (2008, I 2 ).

It is easy-and reductive-to point to Perez's overtly political and resistive stance and Howard's seemingly accomodationist one as examples of positive and negative strategies. Rather than indulge in this ideological rigidity, I look at the ways that both authors pick and choose their strategies and exhibit "resistance and compliance to US discourses" (Monnig 2007, I8) about belonging, citizenship, power, and identity. While Perez overtly states that the goal of his project is to "re-territorialize" the Chamorro language, his body, and, by extension, his Chamorro identity, Howard also engages in a negotiation with the discursive formations of identity surrounding Chamorro-ness, albeit in a more oblique manner.

It is important to keep in mind that these two authors are from different generations and thus that the acceptability of certain discourses has changed. As Stuart Hall has pointed out: "A discourse is a group of statements which provide a language for talking about-i.e., a way of representing - a particular kind of knowledge about a topic. When statements are made within a particular discourse, the discourse makes it possible to construct the topic in a certain way. It also limits the other ways in which the topic can be constructed" (1996, 205). Howard and Perez provide glimpses of the changing availability of modes of indigenous activism at different times. What they have in common, however, is their use of the body to stand for Guam itself and to recuperate the marginalized into the mainstream. The island's marginal status results from the fact that Guam is a territory, but it is an unincorporated one; it is a colony of a nation that firmly disavows its colonial nature; and the statutory nature of its status 
and citizenship means that the US citizenship of its people is contingent on Congress and that it does not have the full protection of the Constitution like the residents of the fifty states-which adds up to an in-between status for the natives of Guam.

For Howard, the body represents Guam's political and judicial standing. His mother, portrayed as a beautiful, smart, and patriotic woman, is the same woman who is mistreated, suffers, and dies during World War II under the Japanese occupation. Her attitudes and treatment by both military regimes are metaphors for the colonization of Guam by the US and Japanese governments and the island's continued neglect, except in military matters, by the United States. While the narrative follows a tale of patriotic suffering meant to exemplify the same in the people of Guam, there are several key moments in which the US government's imperial rule in Guam comes under scrutiny. Perez focuses on the ways that the genealogy of colonization is evidenced both within and on the body. He accomplishes this through his mixture of English and Chamorro (the native language of Guam) and an interlacing of history, botany, political activism, and personal voice. His poems serve to remind his readers that despite the layers of dialogue that are given authority through science and government, the voices of the people will always shine through.

\section{The Supreme Court, Guam, and US Imperialism}

In order to appreciate the current situation in Guam and the position of these two writers, it is necessary to understand some of Guam's military and judicial history. Ferdinand Magellan "discovered" the island in I $52 \mathrm{I}$, and the Spanish colonized it until I 898 when it was ceded to the United States-along with Cuba, Puerto Rico, and the Philippines-for twenty million dollars as part of the victor's spoils in the Spanish-American War. From I 898 to I94I, Guam was under the control of the US Navy; then in I94I, the Japanese invaded and occupied the island with a particular brutality and renamed the island Omiya-jima (Holy Shrine Island). On 2 I July 1944, the US Armed Forces recaptured and "liberated" Guam (Rogers I995, I 5, I08, I62). Since that time, Guam has been a US territory. It is now home to six military installations and about I 5,000 military personnel and their dependents. Almost one-third of the island is off-limits to its native population because of these military installations, and there are currently plans to relocate a US Marine Corps base from Okinawa, Japan, to Guam, which would involve the relocation of another 8,000 marines 
and approximately 9,000 of their dependents, increasing the military population by almost 50 percent. This massive increase would further strain both the natural environment and the relationship between the residents and military personnel. These are the bare facts, but these facts hide a wide-ranging set of meanings and memories.

The motto of Guam is "Where America's Day Begins," but in the continental United States, Guam is a mostly forgotten colony. Overshadowed by Puerto Rico in terms of immigration visibility and population, shuffled aside in critical work about Filipinos and US colonialism, and forgotten in legal writings about Island nations and citizenship that tend to focus on Hawai' $i$, the people of Guam are truly invisible US citizens. Although the people of Guam are US citizens, Guam is not a US state, so they can neither vote in national elections nor have a voting representative in Congress or the Senate.

This ambiguous situation occurs for several reasons, but the primary one dates back to the Treaty of Paris between Spain and the United States, signed in December I 898. The treaty stated, "The civil rights and political status of the native inhabitants of the territories hereby ceded to the United States shall be determined by the Congress" (quoted in Rogers I995, I I3). And this is still the underpinning of Guam's liminal status. I use the term "liminal" here, as opposed to "marginal," since Guam is between two different stages of association with the United States: it isn't a self-governing commonwealth like Puerto Rico because the United States still has political and budgetary control over Guam, and, unlike a state, Guam is not afforded all of the constitutional guarantees. This island is officially an "unincorporated territory," which means that while it is not of the United States, it belongs to the United States. In other words, the Doctrine of Territorial Incorporation (which states that the Bill of Rights shall be binding in states) technically doesn't apply in Guam, because it is a territory that is unincorporated. And, like the citizenship of Guam's residents, the protections afforded by the Constitution and citizenship are contingent. In I950, after years of agitation by both Guam residents and US activists, ${ }^{1}$ President Harry Truman signed into law the Organic Act, which created a domestic legislature, and while Guam is now self-governing, it is still subject to the plenary power of the US Congress, and the US military still maintains a considerable amount of power. This act was made to be effective retroactively to 2I July I950, the sixth anniversary of Liberation Day (Rogers I995, 22I-222), reinforcing the association between the US government and notions of freedom. Despite this change in government from 
the US Navy to its own people, the legality of Guam's status still remains under the doctrine of the Insular Cases, a series of US Supreme Court cases decided during the period I90I-I9I4 that attempted to answer the question of whether the Constitution followed the flag, ${ }^{2}$ which means that Guam is without any possibility of statehood or independence. These cases also created a new category of people, the "noncitizen national," in order to "describe a new status of people who lived under the U.S. flag without the full range of constitutional protections that flag normally carries" (Kerber 2005, 734). Indeed, the justification for this peculiar category was given by Justice Henry Billings Brown in one of the key cases, Downes $v$ Bidwell (I 82 US 245 [US Supreme Court I90I]): "We are also of the opinion that the power to acquire territory by treaty implies not only the power to govern such territory, but to prescribe upon what terms the United States will receive its inhabitants, and what their status shall be in what Chief Justice Marshall termed the 'American empire.' . . Indeed, it is doubtful if Congress would ever assent to the annexation of territory upon the condition that its inhabitants, however foreign they may be to our habits, traditions and modes of life, shall become at once citizens of the United States." Although the people of Guam are US citizens, this way of thinking-that Guam itself is still too "foreign" to be fully admitted into the union of the United States and afforded all of its protections-is still the case. While "law is the apparatus that binds and seals the universality of the political body" (Lowe I996, 8), it is clear that in this case the bodies on this island are particularized rather than universalized through the very peculiar form of their US citizenship, demonstrating that it is clear that some citizens are more equal than others.

The larger question in Howard's and Perez's texts concerns identity and how nation and citizenship are bound up with that identity, because as Vivian Dames succinctly pointed out in her dissertation, "Citizenship is not just a certain status, defined by having a bundle of rights and responsibilities. It is also an identity and an expression of membership and belonging to a political community" $(2000,634)$. This sense of identity and belonging can be difficult for anyone to obtain, but one can only imagine that it is even more vexing for those for whom classificatory categories like "nation," "ethnicity," and "citizenship" are all contested terms. Another reason that I read these particular texts from Chamorro authors is for the way that they shed light on the contested and variable nature of the nation-state compact, a bargain that is usually imagined as sturdy and inalienable. 
Linda Kerber's essay "Toward a History of Statelessness in America" (2005) uses Hannah Arendt's Origins of Totalitarianism (2004) to ground her examination of the relationship between these supposedly inalienable "rights of man" and national belonging. While these rights-including freedom, the pursuit of happiness, and a right to life and participation in civic life-are supposedly universal and abstract, we see in fact that they are very particularly rooted in national belonging. Rights that are supposedly universal become unenforceable for people who lack a government to guarantee them. As Arendt has pointed out, "if the laws of their country did not live up to the demands of the Rights of Man, they were expected to change them, by legislation in democratic countries or through revolutionary action in despotism" (quoted in Kerber 2005, 732). The issue is that while Guam technically belongs to the US nation, the island is invisible in the everyday workings of government because of its perceived remoteness and its small population. The people of Guam have attempted to change the terms of their status through political and legislative channels. The United States, however, has thwarted almost all attempts through simple inaction or amnesia. As Laurel Monnig pointed out, "Lost and forgotten petitions filed in a black-hole bureaucratic drawer somewhere, more important agendas to attend, and the circuitous dead-end negotiations.... It speaks to the fact that the US (particularly naval) administrations wanted Chamorro practices themselves to be filed away and forgotten" (2007, 58-59). By "forgetting" about Guam, the United States can also conveniently forget about its own status as imperial nation. However, authors such as Howard and Perez insistently work against this amnesia and instead use their particular types of knowledge to insist on making visible what the United States wants to hide.

The various discourses from and about Guam, legal and otherwise, embody the contradictions that occur when we have the discourse of liberation and rights side by side with the denial of those rights under the colonial rule of the American empire. Guam's status as "not-US" functions as the state's "Other" and the United States is able to fortify its own sovereignty through its imaginative opposition to places like Guamplaces that are "dependent," "invisible," and "non-sovereign." 3

While there are many justifications for the United States to continue to ignore the wishes of the indigenous people of Guam, one of the most compelling reasons that it wants to keep Guam hidden is so that is can continue to expand its military operations on the "American Lake" without the inconvenience of dealing with sovereign foreign nations. Guam has 
the advantage of being US soil but without the pesky social and political uproar that would accompany similar measures in the continental United States or in other nations. The long history of Guam's use as a military base of operations in the Pacific by a colonial administration continues without abatement, and we can see how dealing with this long history necessarily shapes the daily lives of those living there. In Mariquita, the narratives of paternalistic racism, the use of the female body as a metaphor for the land, and the cloaking of militaristic intentions with the rhetoric of romantic love are all present.

\section{Mariquita: A TRAgedy of GUAM}

This short text is a biography of the author's mother, Maria Aguon Perez, and her marriage to a young enlisted man, Eddie Howard. The text is focused in equal parts on Howard's parents' courtship and on the occupation of Guam by the Japanese. In addition to the straightforward narrative, the text is supplemented by family photos, copies of official depositions regarding the disappearance of Mariquita, and a newspaper clipping from the Honolulu Advertiser detailing the sad story of the two children whose mother was presumably murdered by a Japanese officer. Although Howard attempts to negate any sense of American imperialism and shapes his book into a particular narrative that fits in with US military aims, there are moments that erupt, seemingly beyond his control, when he is describing his mother.

In the book's title Howard uses the economy of allegory, perhaps unconsciously, to effeminize Guam and to make it an object of pity. Howard is able to gain his readers' sympathy through the trope of victimization. Viet Nguyen pointed out, "One of the most important representations of the Asian American body politic in the post-Vietnam War period is that of the victim" because this is one of the "few 'sympathetic' representations of Asians and Asian Americans in dominant American discourse"; it is this categorization "that allows its subject to enter into the arena of public discourse and political representation with a degree of power, albeit only the power to forgive and exploit guilt" (2002, 27, I IO). By choosing to tell his mother's story rather than focusing on his own, Howard is able to accomplish two things: He is able to use Mariquita's feelings of patriotism and anger as a stand-in for Guam's ambivalence about the American military presence, and he is able to cloak those criticisms in the mantle of victimhood and thus places this narrative in a sympathetic light. 
Additionally, a feminized Guam also lends itself to stereotypes of tropical femininity and pleasure, a type of femininity in need of rescuing from other potentially threatening occupiers. This linkage of island with woman also serves to portray Guam as a "tragedy" because of the Japanese occupation and the protection provided by its American liberators. By using these tropes, Howard is cannily able to introduce critiques of the US military colonial regime through his mother's dialogue, which in turn invites a mainland audience to identify itself as masculine rescuer and to obfuscate its colonialist regime through rhetorics of romance and liberation. However, this masking of his voice through his mother's is not without its own problems, as it is through Howard's use of this rhetorical switch that he effaces Guam's history of centuries of Spanish colonization and US military occupation prior to World War II. Instead, Mariquita's unswerving marital fidelity becomes a metaphor for the steadfast loyalty and patriotism of Guam's residents to America.

Howard's descriptions of his mother fall in line with stereotypical descriptions of Pacific Islander women. He describes her as "a lovely girl, shapely and petite, a pleasing mixture of several of the races that comprised her native culture. . . . Her skin was warm brown, smooth and unblemished." He follows this up, however, with the caveat that "she was not the stereotyped island girl depicted in romantic literature-uncomplicated and submissive" (I986, 2). In fact, the litanies of Mariquita's attributes are in line with many orientalist fantasies of the perfectly submissive Island girl. While Mariquita has several "Western" attributes (such as her working outside the home, her education and religion, as well as her English skills), she is still able to combine these with a strong sense of family duty, a docile and passive personality, and an unswerving faithfulness to her husband. Despite Howard's statement to the contrary, he ends up reiterating not only stereotypes of Island women but also the rhetoric of American benevolence and Chamorro patriotism.

Howard's descriptions of his father's actions and his mother's reactions are meant to encapsulate the US-Chamorro relationship. Just as clearly as Mariquita is meant to represent the sweet and loyal Chamorro, Eddie, Howard's father, is the "right" kind of American who is protective, loving, and understanding. Howard paints a portrait of gentlemanly conduct and chivalrous respect when describing the wooing of Mariquita by his father. Although initially Mariquita rebuffs Eddie's advances, one night when she is walking home with her brother Frankie after the movies, the two of them pass by a bar full of drunk servicemen and a commotion ensues: 
“'Hey, where are you going, pretty girl?' one of them asked. Mariquita and Frankie hurried on, ignoring him. 'Let me come with you. I'll show you a good time,' he continued, leaving the other man and starting after them. Mariquita and Frankie walked faster as the American stumbled along after them. He stopped and shouted, 'You dirty native! Who do you think you are?' Hearing a commotion behind her, Mariquita looked back and in the dim light saw Eddie knock the man down. 'Hurry Frankie,' she said, urging her brother on as tears filled her eyes" (Howard I986, 22).

There are several things going on in this short scene. First is the normalization of the presence of military men in her town. Although the US Navy had governed Guam for forty years by this point, the military presence goes completely unremarked by either the author or by Mariquita. The American presence and intrusion in their city is a given, as are drunk sailors. The second factor to notice is the presumed sexual availability of island women as evidenced in the serviceman's remark, "I'll show you a good time." The naturalized seizure and occupation of the island by Americans is expressed through the way that the sailor assumes that Mariquita is available for the taking. Although Mariquita is walking with another man, the sailor disregards this and lays claim to Mariquita's body. Instead of answering back to the sailor, she urges her brother to walk faster until the man shouts out, "You dirty native! Who do you think you are?" It's unclear whether this racist remark is directed toward Mariquita or her brother, but what is clear is the presumption of superiority, especially marked by the question, "Who do you think you are?" This question, with its layers of indignation and entitlement, encapsulates the arrogance of the military presence on Guam, and this overt display is what finally causes the pair to stop. When they turn around, they see Eddie hit the man in what is to be interpreted as a chivalrous defense of Mariquita's honor, a protection that Frankie is unable to offer, just like the island of Guam is presumed to be unable to handle its own defense. It is clear that this scene is supposed to demonstrate to the reader the honorable intentions of Eddie and, by extension, the honorable intentions of the US military. The racial slur and the disrespect are unmistakably presented as aberrations.

The next chapter, titled "An American in Guam," continues the story of that evening, and Howard goes to further pains to explain the unusual nature of this event by writing, "Life on Guam was peaceful and harmonious. This particular incident was highly unusual because of the racial remark the American had made to Mariquita. The relationship between the Americans and Guamanians was overtly one of friendship and mutual 
respect" (1986, 23). However, the insertion of the word "overtly" clues the reader in that even Howard realizes he is being disingenuous. Why use the word "overtly" at all if there is nothing covert occurring? Seeing this word, we realize that the opposite is true, and indeed the next sentence contradicts the author's assertion of racial harmony: "Racial prejudice, if any existed, was hidden, although it could be argued that it did in fact exist because there was a private school for military children and the social clubs and party lists were very exclusive" (Howard I986, 23). So, which is it? Does racial prejudice exist openly or is it hidden? It's both, of course. Howard says one thing-that there is racial harmony-but his examples of the sailor shouting out to Mariquita and the existence of the separate schools and exclusive social lists point to another reality. In this short scene we see how Mariquita and her experiences are used as a symbol of the island of Guam, a place that is sweet and loving and yet needs protection, and Eddie becomes a symbol of the might and goodness of the United States. Just in case we haven't understood this connection yet, Howard writes, "The military personnel were proud to serve their country and felt that they were personal representatives of America" (1986, 23). While Howard attempts to write this scene as a case in point of the inherent benevolence and chivalry of the US-Guam relationship, his example provides more than he bargained for.

As it turns out, Mariquita had been pressed into service as a representative of Guam before, and Howard quotes extensively from an interview that Mariquita gave to Collier's magazine, which appeared in the I8 April 1939 issue. After describing Mariquita's beauty and femininity, the interviewer asked her about the "American School," a private school for military dependents as well as for native children. Mariquita's reaction was more complicated than would have been expected of a patriotic Chamorro: "'What do they mean by that name?' . . . 'Aren't all schools in Guam American schools? Don't we salute the same flag, sing the same patriotic hymns in our classrooms, love and respect the same great men?"' The interviewer commented, "You would be constitutionally unable to disagree with anything Mariquita says." Later in the article, Mariquita noted, "Only lately ... have civics been taught. I guess they didn't want us asking too many questions about citizenship" (quoted in Howard I986, 29-30). These trenchant observations demonstrate that even though American history and nationalism have been accepted by the colonial subject, the very questions Mariquita asked demonstrated her (ie, Chamorro) awareness of the ruptures caused by race within the production of patriotic colonial 
subjects. In this moment, Mariquita exceeded the expected boundaries of the assimilated native. Instead of being grateful for her limited inclusion within the United States, Mariquita tartly pointed out, "I guess they didn't want us asking too many questions about citizenship." Rather than simply answering her interviewer's question, she turned the tables and asked pointed questions about the nature and meaning of citizenship. While Howard attempts to portray his mother as the idealized, patriotic Chamorro, her actions and answers prove to be too complex. The interviewer pointed up differences in notions of legal citizenship in his mincing answer that "constitutionally" we (presumably meaning "real" white Americans with full citizenship rights) cannot disagree, leaving unsaid the assumption that, of course, in all sorts of other ways we can disagree with Mariquita's claim to full citizenship.

Howard's text is riddled with instances of Mariquita asserting her American-ness. However, the author makes clear that it is the harsh experiences of Mariquita (and by extension all residents of Guam) during the Japanese occupation of Guam that earned her especial claim to US citizenship. The portrayal of the victim status of Mariquita and other Guamanians performs two related and important functions. ${ }^{4}$ While enlistment in the armed services was not possible for Mariquita as a woman, in Howard's portrayal her incarceration in a concentration camp in the interior of the island and her forced servitude to an officer in the Imperial Japanese Army substitute for the sort of military service that would have been the norm for a man. It is through military service or its equivalent that those who would otherwise be marginalized citizens can claim an elevated form of citizenship that privileges their criticisms and dissent against their colonizer.

Fully half of the text is concerned with the invasion and occupation of Guam by the Japanese and subsequent liberation by US forces. Typical in almost all public discussions about Guam and World War II, both on and off the island, is the emphasis on Japanese cruelty and American benevolence. This well-worn chorus ranges from a work like Mariquita to the official National Park Service's guide to the National Historical Park in Guam, which proudly announces, "This unique National Park is the only site in the National Park system that honors the bravery and sacrifices of all those who participated in the Pacific Theater of World War II" (NPS 20I0), emphasizing Guam's status as a military memorial rather than a unique ecosystem or an island nation. Vicente M Diaz, one of the foremost scholars on Guam, has stated that this particular type of discourse demonstrates the "political imperatives of a postwar American colonial history 
and historiography" but doesn't deal with "unresolved issues such as postwar land condemnations, war reparations ... Guam's neocolonial status, and ... the unprecedented economic and social growth and impact on indigenous culture and the land itself" (200I, I 56). This narrative of patriotism continues to be used even when it is clear that America's interest in Guam is almost purely for military and strategic reasons rather than from some sort of altruistic desire to free Guam and its people from oppression.

In the case of Guam, the narrative of occupation and liberation is one that has been employed ad nauseam. Diaz pointed out, "On the other hand, there are other stories that not only do not support the dominant narratives of liberation, but also do not have the cultural or political capital to trouble them in public. ... These marginalized stories of life at the margins have the potential to disrupt the dominant paradigms but don't because the social and political costs are tremendous and the returns have yet to present themselves" (200I, I 59). Thus, Mariquita's pointed observations about the contradictory site of Chamorro-ness and US citizenship must be embedded within a larger narrative about patriotism and loyalty.

The romantic relationship between Mariquita and Eddie stands in for the heterosexual normalcy that underpins nationalism, which in turn requires the maintenance of masculinity and domination. Naoki Sakai explained it thus: "Characteristically, the colonial power relation is articulated to the sexual relation in double registers. The domination of one group of men by another group of men is reinscribed in the domination of women by men" (20II, 207-208). But this power is cloaked in terms of romantic love because romance implies a mutuality, a consent, and even a desire on the part of the dominated and precludes the sociopolitical equivalent of rape, a violent imposition of an unwanted attention with the intention of harm and overt authority. Howard's narrative implies a desire for union with the United States, just as he envisions his parents' marriage as an equal partnership.

Similar to the vocabulary of romantic love, the rhetoric of patriotism is a language of devotion. An example of this devotion occurs at the end of the book, after Mariquita has been forced to work as a servant for the commanding officer in the Imperial Japanese Army. There comes an oddly protracted scene, covering almost three pages, of Mariquita's insistence that "she would rather die than disgrace her husband by sleeping with the Japanese" and that she "could not respect" herself and face her children if she had to be unfaithful to her husband. Despite her mother's pleading to do whatever it takes to survive, Mariquita insists, "Eddie is 
the only one who will ever touch me" (Howard I986, 75). Like a soldier, Mariquita refuses to surrender and instead honorably chooses to die in service to her country. Mariquita's love and devotion are unquestionable, and her rebellion against one type of imperial domination paradoxically demonstrates her utter submission to another imperialism. In addition to Mariquita's (ie, Guam's) patriotic devotion, Eddie himself has become a stand-in for the United States and has demonstrated his masculinity by defending Mariquita's personal honor, and the US military will soon demonstrate its strength and dominance through the decisive defeat of the Japanese.

In Howard's short biography of his mother, we can see how the forces of nationalistic narratives shaped his parents' story. Cloaked in the language of romance and mutuality, the linkage of Mariquita and Eddie with Japanese occupation and American liberation demonstrates the ways in which the female body in particular is manipulated in order to ameliorate anxieties about colonization and domination in the American empire. Although Howard cleaves to the predictable narrative arc about patriotism, love, and gratitude expressed by the people of Guam, he also uses this account to insert serious questions about the value and meaning of US citizenship for the people of Guam.

\section{INCORPORATED BODY, UNINCORPORATED TERRITORY}

Starting with its very cover, Craig Santos Perez's poetry chapbook from unincorporated territory [hacha] proclaims the layering of Spanish and American colonization over the island of Guam. The graphic is a series of thick red lines superimposed on a white background, clearly meant to represent the stripes in the US flag. The stripes are not smooth, however. Midway through the horizontal stripes a disturbance begins, and the topmost stripe becomes a bell curve. Next to the bump is the title, from unincorporated territory, and underneath these words and within brackets is the Spanish word "hacha," meaning axe. The title, of course, refers to the legal status of Guam and of its people. But more than that, Guam is the bump in the otherwise smooth narrative of American incorporation of diverse peoples under its flag, and Perez's poetry is meant to slash its way through, much as an axe slashes its way through a closed door.

This volume is about the same length as Howard's biography, but that is almost all the two have in common. While Howard's narrative is a realist and linear narrative, Perez's poems are both a lament and a celebra- 
tion of Guam. Perez's preface combines quotes from the Territory Clause of the Constitution, a biblical quotation, a statement about Guam's cartographic representations, and an encyclopedic entry about its Mercator locale. From there, Perez goes on to discuss the geographical creation of Guam and the Insular Cases and quotes from Downes $v$ Bidwell. These fragmentary "official" entries, spliced with personal observations, set the tone for the rest of the text. The interweavings demonstrate the ways in which Guam has been subsumed under the layers of words written and spoken about it, just as the volcanic mountain that forms Guahån (the Chamorro name for Guam) and its history are mostly submerged.

Perez also quotes from two other authors in his preface. The first is a poem published in 1986 by Robert Duncan titled "Uprising: Passages 25 " that begins, "Now Johnson would go up to join the great simulacra of men, / Hitler and Stalin, to work his fame / with planes roaring out from Guam over Asia, / All America become a sea of toiling men" (quoted in Perez 2008, I0; Perez's italics). Perez explains, “'Uprising' is one of the few poems in American poetry that mentions Guam. In the poem, however, 'Guam' only manages to signify a strategically positioned US military base. ... This 'redúccion' of 'Guam' enacts the cultural, political, geographic, and linguistic 'redúccion' that has accrued from three centuries of colonialism" (2008, II). ${ }^{5}$ To work against this reduction of "Guam," Perez reclaims the adjective "unincorporated" as well as the preposition "from" and uses these words as a free place to begin. As he says, "From indicates a particular time or place as a starting point ... from imagines a source, a cause, an agent, or an instrument; from marks separation, removal, or exclusion; from differentiates borders" (2008, I2). To be from someplace is to mark the movement away, the simultaneous claiming of a locale as well as the acknowledgment that one is no longer there. Perez recognizes the agency in his movement, but he also recognizes that his movement means separation.

Each poem in this collection includes from in its title. Perez explains that this "bears its weight and resultant incompleteness," and he also explains that the Chamorro words enclosed in brackets in each poem symbolize how, in "the ocean of English words, the Chamorro words in this collection remain insular, struggling to emerge within their own 'excerpted space" But it is much more than words struggling: "These poems are an attempt to begin re-territorializing the Chamorro language in relation to my own body, by way of the page" (Perez 2008, I2). However, Perez's poems don't explicitly reference his own body but rather the ways that 
the bodies of others have been used during the various waves of colonization and the ways that those bodies bear the marks of that usage. This oblique identification causes us, the readers, to rethink the ways which bodies literally and metaphorically become territorialized. Perez's move to "re-territorialize" his body is a move to reclaim his own language and discursively produce his identity.

The second poem in the collection, "from achiote," is a collage of pictures; encyclopedia entries about the achiote plant; a list of various names for the plant; poetic sections about the narrator's grandmother; historical information about Father Sanvitores, an early Spanish priest who was killed on Guam in I672; and reflections about the current state of Guam. This poem utilizes the symbolization of sight, history, and memory, and the connections between the land and body in order to remark on the layers of occupation and blood that have been visited on the island of Guam by successive waves of intruders. The inclusion of historical and legendary information about Father Sanvitores acknowledges and claims all of the genealogy of Guam, and it is through Perez's refusal to claim or idealize a precontact past that he begins to "re-territorialize" Guam for himself.

While some nonnative flora and fauna, languages, religions, and foods have become incorporated as "traditional," others are still "un-incorporated." Achiote becomes symbolic as a plant that is both-it is a nonnative species that is used in now traditional Chamorro dishes like chalikiles and hineksa agaga. As Perez explains, "the achiote plant is indigenous to central and south america and the caribbean. it was transported across the pacific to southeast asia by the spanish colonialists. the achiote has been traced back to the mayans" (2008, 17). The adaptation of the achiote plant becomes a metaphor for the connection between the far-ranging colonies of the Spanish, leading us to ponder other connections and disconnections between the histories of various peoples. Some connections between colonized and colonizer are unexpected, such as the ones between Father Sanvitores and the achiote plant, exploring the symbolization of sight and blindness:

my grandmother leans over the achiote plant and picks its ripe "shells" our hands among the red veined leaves an attractive pink flower made it a popular hedge plant in colonial gardens "ahi" she says when i

touch the flowers 
“don't touch your eyes"

- the frail blind body of father sanvitores [I672]

is led around by a rope tied to his waist he refused glasses because "if the poor were too poor for glasses"

etc evangelizare pauperibus misi te

a small satchel: a breviary, a new testament, lumps of sugar for children who could recite their prayers and

catechism lessons

\section{flagellation physics disciplina a cilice}

he's always i fi'on-mu: a sunday school warning: if you don't say your prayers you wake

with bruises [no : ahi]

[achiote can be used to treat skin problems, burns, venereal disease, and hypertension]

$$
\text { -(Perez 2008, I8-I9) }
$$

The harvesting of the achiote plant by the grandmother and grandson emphasizes their family connection, but the grandmother's warning to her grandson to not touch his eye for fear of injury, followed by the mythos of Father Sanvitores's piety as exemplified through his refusal to wear glasses, links the two figures through their potential loss of sight. Perez's poem uses the trope of blindness and insight to reposition the perspective of the reader as well as to make linkages between colonizer and colonized.

Through the descriptive narrative portion of the poem, we "see" the narrator's grandmother picking achiote and assume that this moment marks "tradition," but then we learn that achiote is an introduced plant. The description of Father Sanvitores's refusal to utilize the technology of glasses can be read in a few ways. It is often used as an example of his piety and his dedication; however, his refusal to wear glasses actu- 
ally makes him a larger burden on the natives because he must be led around by a rope tied to his waist, thereby reinscribing the hierarchy of power through the physical labor of those who have to lead and carry him around the jungles of Guam. A possible third way of reading this scene is as a potential subversion of Father Sanvitores's authority since he depends so heavily on the natives to get around. These multiple ways of interpreting one scene demonstrate that how we "see" and understand is contingent on a variety of factors.

Father Sanvitores's usage of the cilice, a coarse shirt made of horsehair, and his self-flagellation are both well-known parts of the legend of his piety. His denial of his body is brought about by his abuse of his body, making its physicality all the more apparent. The Sunday school warning that "he's always i fi'on-mu" (near you) reiterates the panoptic eye of the Christian god through the almost-blind priest and threatens physical punishment as a result of metaphysical disapproval. In other words, the body becomes the bearer of meaning in a readable way for a Catholicized population, and the scars and bruises on the body tell a story of sinfulness and disappointment. The physical manifestation of meaning is made with linkages of other marked and scarred bodies in other poems in this chapbook such as "from ta(la)y," which I analyze a little later. These repetitions serve to underscore the way that history is repeated and resides in the land and its people.

Another technique Perez utilizes is one of delayed translation. In all of his poems, Perez will use a Chamorro word and then translate it either in a footnote, later in the same poem, or even in another poem altogether. This technique is both frustrating as one goes flipping through to find the meaning of a particular word and illuminating since it also emphasizes the ways that words as well as stories contain a myriad of potential meanings. For example, the translation of the word "ahi" in the grandmother's warning comes right after the cautionary tale about the necessity of saying one's prayers, and it serves two purposes. One is to provide the actual translation of the Chamorro word used on the previous page- "no"and the other is to negate the warning to say one's prayers and can thus be read as a refusal to believe the superstition of bodily injury if one isn't properly pious. We don't learn what "i fi'on-mu" means until two pages later, where it is located on the bottom right-hand corner of the page, after a tale about the unwanted baptism of Chief Matapang's daughter by Father Sanvitores. In this location, the translation also serves a double meaning. The deception of Father Sanvitores and the murder committed 
by Matapang are "always with you," but we can read the "ahi" (no) as negating this as well. Perez's mixture of these stories and histories works against any revisionist claims to a pure "precontact" past. Rather, Perez mixes forms and stories and languages in order to claim a hybridized past-not the hybridized past that is so valorized by postcolonial theorists, but rather a past that combines both the strong and the weak, the fateful and the faithless.

Perez's positioning of the translations and explanations of words and phrases serves to let us know that there are at least two versions of each story and that we don't always know or understand the multiple versions of the stories until later. This layering of words serves to remind us that modern-day Guam contains the stories of multiple colonizations and occupations, military violence, and economic rupture. The use of English with the Chamorro words in brackets prompts us to realize that within the body of English lies a fracture of meanings, just as there is a multiple and fractured meaning carried within each person that is inherited from the lives and deaths of Spanish priests, soldiers, native Chamorros, and others living on Guam.

The poem also includes a few lines about the Japanese occupation: "my grandmother used achiote to make chalikiles and hineksa agaga so young when the japanese army / invaded and renamed hagåtña 'akashi' / - the 'red city'-'bright red stone'" (Perez 2008, 23). These few lines reiterate the renamings that have occurred again and again in Guam and remind readers that the Japanese occupation, an event that is usually given precedence over Spanish colonization, is really only a few lines in a long story of occupation.

However, another poem titled "from ta(la)ya" ("taya" means empty and "talaya" is a type of throw net used for fishing) goes into more detail about the Japanese occupation; it begins:

"ichi ni san shi go roku shichi hachi kyuu juu" my grandmother recites from the couch when

she

sees him bowing

[the japanese military forced men to dig massive and elaborate tunnels in yigo and agana to connect military encampments]

she struggles to get up from the couch and stands next to him and tries to bow also but her back 
instead she sings: $\quad$ eighth of december nineteen forty one people went crazy right here in guam

ob $m$ r sam, sam, my dear uncle sam won't you please come back to guam"

-(Perez 2008, 80)

This first stanza begins by counting from one to ten in Japanese, and it ends with a modified version of a wartime song popular during the occupation. Although the "him" in the poem is not identified, his bowing and the grandmother's recital of Japanese words, as well as the bracketed information about the brutality of the Japanese occupation, suggests a Japanese visitor. But is the visitor there to apologize? To memorialize? His purpose is unclear, and the visitor himself is unimportant except as a bodily reminder, like the grandmother's aching back, of those difficult days. The explanation of the difficulties under Japanese occupation is bracketed and set aside-remembered, but not an integral part of the poem. However, as Perez noted earlier, the words and phrases placed in brackets "remain insular, struggling to emerge within their own "excerpted space" (2008, I2), and they serve as a linkage between the Japanese occupation and the current US military occupation and the ways that Guam's people are used as cheap labor for the current regime as well.

The ditty that the grandmother sings is a case of one occupier's words replacing another's. Does it really matter whether the grandmother is counting in Japanese or chanting a date in English? Only to the occupier. The singsong quality of both recitations reduces them to mere sounds, but this diminishment also serves to underscore how tightly the Japanese and American occupations are bound together. After giving a historical date, the ditty employs the language of kinship and desire. However, the original song does not include the words "people went crazy right here in guam." This newly inserted line no longer absolves the people of Guam, nor does it cast the Americans in a completely blameless light. The implication is that everyone went "crazy" in Guam on this day. The last couplet of this stanza evinces a desire and an invitation for the Americans to return, which re-codes the verse as "an apparatus for remembering many different things: it recalls a Chamorro story of intense suffering, of enduring loyalty to the United States, and finally, of intense gratitude and love toward America for returning to 'liberate' the Chamorros" (Diaz 200I, I 57). This "intense gratitude" is reflected in the invitation for "uncle 
sam" to return to Guam, which portrays desire and longing for the US military to come back and to "save" the people of Guam. While the initial arrival of the US military was undoubtedly welcome, it is also clear that they have long overstayed their welcome (as evidenced in the third poem I analyze, "from lisiensan ga'lago").

The last lines of "from ta(la)ya" reflect on the irony of the memorialization of the war in Guam, an irony that seems to be lost on the officials creating celebrations like Liberation Day and locales such as the War in the Pacific National Park. The man whose story is being told remains anonymous and representative of the experiences of men both during and after the war:

he spent two years in forced labor camps

soldiers came in their truck early morning roll call and drove him and others to build the airstrip in barrigada

picks and shovels sacks and shoulder bars

...

he was then stationed in asan to construct machine gun encampments

first they made the forms

mixing salt water from the beach with cement and sand

he said "the quality of the concrete was not good because of the salt"

after they made the foundation and retaining wall they set the concrete

[Guahan remains one of the few official colonies in the world]

he said he never carved his initials into the concrete he said he even tried to avoid leaving fingerprints

the next morning they tore out the form

twenty years later he would return to Guahån as the superintendent of the national park service war memorial he said "my job was to preserve things that i wasn't willing to build" 
This man's wartime service is ironically reflected in his present as the guardian of memorials of a time he doesn't want to remember. The temporary and crumbling nature of the Japanese occupation is contrasted with the ever-lengthening duration of the American occupation. The attempts by the man in the poem to erase any sign of his involvement and his forced labor in building the foundations is cruelly compared to his current occupation of preserving the signs of his own servitude. This unwilling memorialization points to one of the ways in which "an American fiction of itself was inscribed and maintained, fought for and protected in and on places like Guam ... to accomplish that specific act of historical and cultural construction" (Diaz 200I, I 57-I 58). Those who have the most to do with war are those with the least amount of power to object and their desires are often overlooked.

The next poem, "from lisiensan ga'lago" (Perez 2008, 83), consists of nine words surrounded by a box. The words are a mixture of English and Chamorro, and only one word (attadok) is not crossed out:

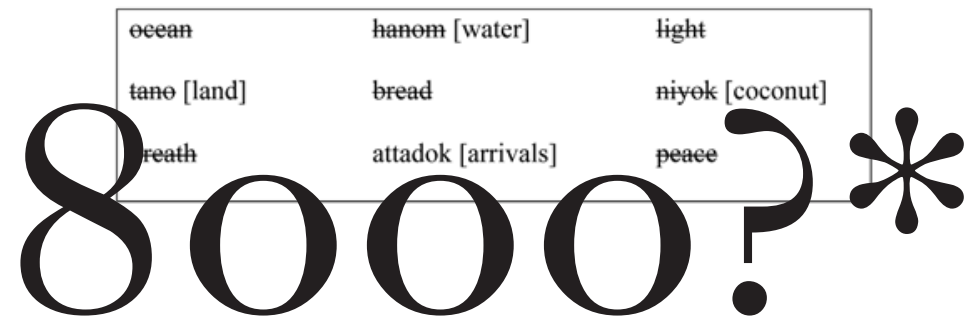

Superimposed on this box of words is the number " 8000 ?"* in dark, supersized font. Below this montage are the words "please visit:" and a list of three websites dedicated to news about Guam and the decolonization process. The invitation in the previous poem expressed in the popular wartime ditty for Uncle Sam to come back again has been answered, and the number " 8000 " refers to the approximate number of marines who are scheduled to be deployed to Guam from Okinawa as part of a 2006 agreement between the United States and Japan for a realignment of troops in Asia (Bevacqua 2009). In this poem, the polite exhortation "please visit" directing the reader to the websites has a different meaning; instead of asking US troops to come back to Guam, it is vehemently asking them to go away. The number " 8000 " overwhelms the rest of the words on the page, just as Guam's land and ecosystem are being overwhelmed by this planned massive deployment of troops. In addition to the eradication of natural resources, more abstract notions like peace and light are also engulfed. 
Following this poem is a map showing all of the various US military bases on Guam, which take up almost one-fourth of the island. The question mark after the number leads us to wonder how these 8,000 troops are going to affect Guam, and the asterisk, normally a symbol pointing to an explanatory footnote, leads to nothing. This blankness marks the uncomfortable lack of knowledge and awareness that many people have regarding the consequences of this shifting of military personnel. We, too, are left wondering what is going to happen next and where the explanation for these actions might be found.

These three poems intersperse English, Chamorro, and Japanese in order to explore the various manners of memorialization and the multiple claims of territory underlying the colonization of Guam by the Spanish, the occupation by the Japanese during World War II, and the American liberation and continued military occupation. In each poem, the layers of colonization leave their mark on the body as well as the land, whether it is the bruises that result from a lack of piety, the aching backs of those men and women forced to hard labor during the war, or the overwhelming number of bodies expected to land again in the next few years as part of the expansion of the Marine Corps presence. Perez does not deny or lament the past; instead, he enfolds it into each poem, recognizing that the meaning of the past is malleable and serves the needs of the present, whatever those needs may be.

\section{Using the Past, Choosing the Future}

In a place like Guam, identity, narrative, and history are bound together, and by examining these two pieces of literature from Guam, we are able to further understand the depths of the paradoxical nature of citizenship under an imperial flag. We can also begin to understand the difficulties of trying to balance a narrative between discourses that adhere to acceptable rhetorics of liberation and freedom, thus increasing their chances of being heard, and more resistive texts and ideas, which diminish the same possibilities. In her essay "The Idea of Showa," Carol Gluck said, "In the open debate over national history ... the past was itself a medium, in which fundamental political, social, and cultural issues were being expressed or contested on the terrain of public memory" (I992, 2). Perez and Howard draw on the past to look toward two different futures. Howard utilizes the biography of his mother to make the argument that Guam "deserves" to be fully included in the national body politic of the United States, while 
Perez's work looks to the past in order to say that "enough is enough" and to envision a free and sovereign future for Guam.

I'D LIKE TO THANK MANY PEOPLE for their help with this article. The anonymous reviewers showed me the best part of our scholarly community: they shared ideas, gave thought provoking critique, and pointed me to other avenues of fruitful research. I am so thankful that they gave their time, effort, and care so freely. I also need to say thank you to my daughter, Yuki, who was born three days after I finished writing this article. Her impending birth motivated me like nothing else to get it done!

\section{Notes}

I See Doloris Coulter Cogan's memoir of the passage of the Organic Act in her book, We Fought the Navy and Won: Guam's Quest for Democracy (2008).

2 For an excellent analysis of these cases, see Sparrow 2006.

3 For an analysis of the ways in which Guam's “exceptional” and non-sovereign status fortifies the discourse of America's sovereignty and might, see Bevacqua 2010 .

4 Here I deliberately use the term "Guamanian" as opposed to "Chamorro" for purposes of inclusiveness because there were Chinese and Japanese immigrants living on Guam at the time of the invasion who were also subjected to the same tortures and abuse that Chamorros were.

5 "Redúccion" is the term that the Spanish used to describe the process of establishing missions, converting natives, and stationing soldiers to protect the missions and priests (Rogers I995, 43).

\section{References}

Arendt, Hannah

2004 The Origins of Totalitarianism. New York: Schocken Books. Bevacqua, Michael Lujan

2009 The Five Ayuyu Generals of Southern Guam. In blog: No Rest for the Awake: Minagahet Chamorro: Chamorro Thoughts on Decolonization, Race, Peace and Art. 28 January. http://minagahet.blogspot .com/2009_OI_OI_archive.html [accessed I I March 20IO]

2010 Chamorros, Ghosts, Non-Voting Delegates: GUAM! Where the Production of America's Sovereignty Begins. PhD dissertation, University of California, San Diego. 
Cogan, Doloris Coulter

2008 We Fought the Navy and Won: Guam's Quest for Democracy; A Personal Memoir. Honolulu: University of Hawai'i Press.

Dames, Vivian L

2000 Rethinking the Circle of Belonging: American Citizenship and the Chamorros of Guam. PhD dissertation, University of Michigan.

Diaz, Vicente $\mathrm{M}$

200 I Deliberating “Liberation Day": Identity, History, Memory, and War in Guam. In Perilous Memories: The Asia-Pacific War(s), edited by T Fujitani, Geoffrey M White, and Lisa Yoneyama, I 55-I80. Durham, NC: Duke University Press.

Gluck, Carol

I992 The Idea of Showa. In Showa: The Japan of Hirohito, edited by Carol Gluck and Stephen R Graubard, I-26. New York: Norton.

Hall, Stuart

I996 The West and the Rest: Discourse and Power. In Modernity: An Introduction to Modern Societies, edited by Stuart Hall, David Held, Don Hubert, and Kenneth Thompson, I84-224. Malden, MA: Blackwell.

Hein, Laura, and Mark Selden

2000 The Lessons of War, Global Power, and Social Change. In Censoring History: Citizenship and Memory in Japan, Germany, and the United States, edited by Laura Hein and Mark Selden, 3-50. New York: M E Sharpe.

Howard, Chris Perez

I986 Mariquita: A Tragedy of Guam. Suva: Institute of Pacific Studies, University of the South Pacific.

Kerber, Linda K

2005 Toward a History of Statelessness in America. American Quarterly $57(3): 727-749$.

Lowe, Lisa

I996 Immigrant Acts: On Asian American Cultural Politics. Durham, NC:

Duke University Press.

Monnig, Laurel Anne

2007 "Proving Chamorro": Indigenous Narratives of Race, Identity, and Decolonization on Guam. PhD dissertation, University of Illinois, Urbana.

NPS, National Park Service

20I0 War in the Pacific National Historical Park. Available at http://www .nps.gov/wapa/index.htm [accessed 4 March 20Io]

Nguyen, Viet

2002 Race and Resistance: Literature and Politics in Asian America. Oxford: Oxford University Press. 
Perez, Craig Santos

2008 from unincorporated territory: [hacha]. Kaneohe: Tinfish Press.

Rogers, Robert F

I995 Destiny's Landfall: A History of Guam. Honolulu: University of Hawai'i Press.

Sakai, Naoki

20I I On Romantic Love and Military Violence: Transpacific Imperialism and US-Japan Complicity. In Militarized Currents: Toward a Decolonized Future in Asia and the Pacific, edited by Setsu Shigematsu and Keith Camacho, 205-222. Minneapolis: University of Minnesota Press.

Sparrow, Bartholomew $\mathrm{H}$

2006 The Insular Cases and the Emergence of American Empire. Lawrence: The University Press of Kansas.

\section{Abstract}

This article analyzes Chris Perez Howard's biography of his mother, Mariquita: A Tragedy of Guam, and selections from Craig Santos Perez's poetry book from unincorporated territory: [hacha] and explores their responses to the continued colonization of Guam by the United States. While these two authors use the same events, namely World War II and the multiple military occupations of their home island, to reflect on the contemporary situation in Guam, I claim that the United States is able to continue its colonization of Guam through the twin practices of denying its own imperial practices and ignoring the pleas of native activists. The United States is partially able to accomplish its denial by using a memorialization of rescue from coercive and repressive colonizers who are portrayed in contrast with its own "benevolent" stewardship of the island. This rhetoric of liberation has been one of the acceptable forms of narrative for past authors, but contemporary authors and activists are beginning to explore other forms of discourse.

Both Perez and Howard use metaphors of the body in order to explore the disjointed nature of Guam's relationship to the continental United States. Howard portrays the dependent position of Guam through the metaphor of the willing and submissive female body of his mother, whereas Perez attempts to reclaim an independent body and nation that is continually under siege from the United States and its military ambitions. Despite their stylistic differences, these two authors both claim recognition for Guam and its peoples.

KEYWORDs: US imperialism, World War II, Guam, Chamorro, military, literary analysis, the body 